\title{
Black carbon semi-direct effects on cloud cover: review and synthesis
}

\author{
D. Koch ${ }^{1,2}$ and A. D. Del Genio ${ }^{2}$ \\ ${ }^{1}$ Columbia University, New York, NY, USA \\ ${ }^{2}$ NASA Goddard Institute for Space Studies, New York, NY, USA \\ Received: 6 March 2010 - Published in Atmos. Chem. Phys. Discuss.: 19 March 2010 \\ Revised: 30 June 2010 - Accepted: 9 August 2010 - Published: 18 August 2010
}

\begin{abstract}
Absorbing aerosols (AAs) such as black carbon (BC) or dust absorb incoming solar radiation, perturb the temperature structure of the atmosphere, and influence cloud cover. Previous studies have described conditions under which AAs either increase or decrease cloud cover. The effect depends on several factors, including the altitude of the AA relative to the cloud and the cloud type. We attempt to categorize the effects into several likely regimes. Cloud cover is decreased if the AAs are embedded in the cloud layer. AAs below cloud may enhance convection and cloud cover. AAs above cloud top stabilize the underlying layer and tend to enhance stratocumulus clouds but may reduce cumulus clouds. AAs can also promote cloud cover in convergent regions as they enhance deep convection and low level convergence as it draws in moisture from ocean to land regions. Most global model studies indicate a regional variation in the cloud response but generally increased cloud cover over oceans and some land regions, with net increased low-level and/or reduced upper level cloud cover. The result is a net negative semi-direct effect feedback from the cloud response to AAs. In some of these climate model studies, the cooling effect of $\mathrm{BC}$ due to cloud changes is strong enough to essentially cancel the warming direct effects.
\end{abstract}

\section{Introduction}

Black carbon (BC), the light-absorbing component of carbonaceous aerosols, warms the atmosphere where it is suspended, and an increase in its concentration is therefore

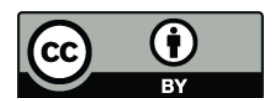

Correspondence to: D. Koch (dkoch@giss.nasa.gov) thought to contribute to global warming. Pollution sources of BC include incomplete combustion of fossil fuels such as diesel and coal, and burning of biofuels and open biomass. $\mathrm{BC}$ also absorbs radiation after it is deposited on snow and promotes snow-melt (e.g. Flanner et al., 2007), further contributing to warming.

BC also affects clouds in ways that are poorly understood. These effects may be warming or cooling and are potentially similar in magnitude to the better-understood warming direct and snow-albedo effects. Like other aerosols, BC contributes to the number of cloud condensation nuclei and therefore affects cloud cover and lifetime. BC may also act as ice nuclei and therefore change ice or mixed-phase clouds. Finally, absorbing aerosols perturb the temperature gradient in the atmosphere and therefore affect atmospheric motions and cloud distributions. This study focuses on these latter $\mathrm{BC}$ radiative effects on clouds rather than microphysical (indirect) effects.

Atmospheric BC suspended near clouds has been thought to contribute to cloud evaporation, originally termed the "semi-direct effect" (Hansen et al., 1997). This loss of cloud cover exacerbates the warming impact of BC. However there are numerous studies that describe additional mechanisms whereby BC may either reduce or increase cloud cover, and thus there may be multiple semi-direct effects. Reduction/enhancement of low to mid-level cloud cover has a positive/negative climate radiative effect, therefore causing a warming/cooling; the reverse applies to thin high-level (cirrus) clouds (e.g. Chen et al., 2000). Note that the radiative impacts of these cloud responses are actually fast climate feedbacks (e.g. Andrews and Forster, 2008) in response to the aerosol direct forcing.

Published by Copernicus Publications on behalf of the European Geosciences Union. 
As $\mathrm{BC}$ is under consideration as a potential global warming mitigation target, it is important that we have a better understanding of its impacts on clouds. Since the feedback from cloud changes can be quite large, the temperature changes associated with cloud redistribution from $\mathrm{BC}$ semidirect effects are potentially much larger than those due to $\mathrm{BC}$ direct effects.

The purpose of this paper is to review the literature on the semi-direct effects of absorbing aerosols. In addition to BC, soil dust particles are also absorbing, so we also include studies focused on dust semi-direct effects. Since many of the studies are regional in scale, we attempt to find common conditions under which absorbing aerosols either enhance or reduce cloud cover. Finally we discuss global model estimates of the semi-direct effect and uncertainties in these model predictions. We construct a tentative framework to organize the various semi-direct effect studies that can be extended or altered by future research, illustrated by Fig. 1. Table 1 summarizes studies that provide semi-direct effect estimates.

\section{Cloud burn-off}

Absorbing aerosols embedded in or near a cloud layer heat the layer and promote cloud evaporation. This was the original "semi-direct effect" first described by Hansen et al. (1997). The effect may be further enhanced due to a low-cloud positive feedback loop as described by Jacobson (2002) in which cloud loss leads to increased opportunity for BC absorption. Cloud burn-off has been reproduced and documented in several studies, especially in cloud-resolving models.

Ackerman et al. (2000) performed large-eddy-simulation (LES) studies of trade cumulus clouds for conditions appropriate for the Indian Ocean Experiment (INDOEX). They showed that boundary layer AAs reduced the relative humidity, increased the rate of cumulus cloud detrainment, and stabilized the boundary layer, resulting in decreased daytime cloud fraction by $25-40 \%$ (see also Table 1).

Hill and Dobbie (2008) used the UK Met Office's LES model with bin-resolved cloud microphysics to study the impact of an absorbing layer of aerosols in the boundary layer on non-precipitating marine stratocumulus. They showed that the BC layer reduced liquid water path (LWP), reduced cloud-top altitude, increased cloud-base altitude and caused a positive semi-direct effect. They also showed that increased cloud condensation nuclei, not necessarily due to the absorbing aerosols but due to increased particle concentrations overall, reduced droplet size and further increased evaporation, boundary-layer dynamics, and cloud-top entrainment (see Table 1).

\section{Altitude dependence of AAs and cloud layers}

\subsection{AA below cloud}

Although BC within the cloud layer enhances cloud evaporation, $\mathrm{BC}$ located above or below cloud can enhance cloud cover under some circumstances. BC below cloud level enhanced cloud cover in the 3-dimensional Eulerian cloudresolving model studies of McFarquhar and Wang (2006) for trade wind cumuli under INDOEX conditions (see Table 1). For experiments with the AAs in the cloud layer, the clouds dissipated as in the studies in Sect. 2. However for AAs below the cloud level, the heating below cloud enhanced vertical motions and increased cloud cover and LWP.

Similar results were obtained over land in the LES experiments of Feingold et al. (2005) for the effect of Amazon smoke on clouds in September (see Table 1). In some cases, smoke emitted at cloud level decreased cloud cover mostly due to its stabilization of the cloud layer, but also due to decreased surface and sensible heat fluxes. Alternatively, smoke emitted at the surface destabilized the surface layer and increased convection and cloud cover. Thus, for these experiments, the cloud cover response depended upon the relative strength of destabilization convective enhancement that increases cloud cover and surface flux reduction that reduces cloud cover. Feingold et al. (2005) pointed out that surface fluxes are less variable over ocean; thus over land the surface conditions play a critical role in determining cloud response.

\subsection{AA above stratocumulus clouds}

Absorbing aerosols aloft generally stabilize the atmosphere beneath. Increased stability over stratocumulus clouds strengthens the inversion, reduces cloud-top entrainment of overlying dry air and thereby enhances the underlying clouds.

The altitude influence of AAs on clouds was demonstrated in the LES experiments of Johnson et al. (2004), designed to study the effect of AA on subtropical marine stratocumulus clouds (see Table 1). As in Sect. 2, AAs within the boundary layer where the clouds reside decreased LWP, and resulted in a positive semi-direct effect. AAs residing both within and above cloud layer also resulted in cloud reduction, although to a lesser extent. However, an AA layer above cloud top increased cloud cover, as it increased the contrast in potential temperature across the inversion, decreased entrainment rate, and caused a shallower, moister boundary layer with higher LWP. The AAs above cloud also reduced downwelling solar flux that can reach the cloud, possibly also decreasing cloud evaporation and increasing LWP. Note however that the decreased solar flux could also reduce surface heating and latent heat flux, providing a competing effect (see Sect. 3.3). In Johnson et al. (2004), the aerosol cloud-radiative effect was nearly equal and opposite to the direct effect. The authors 


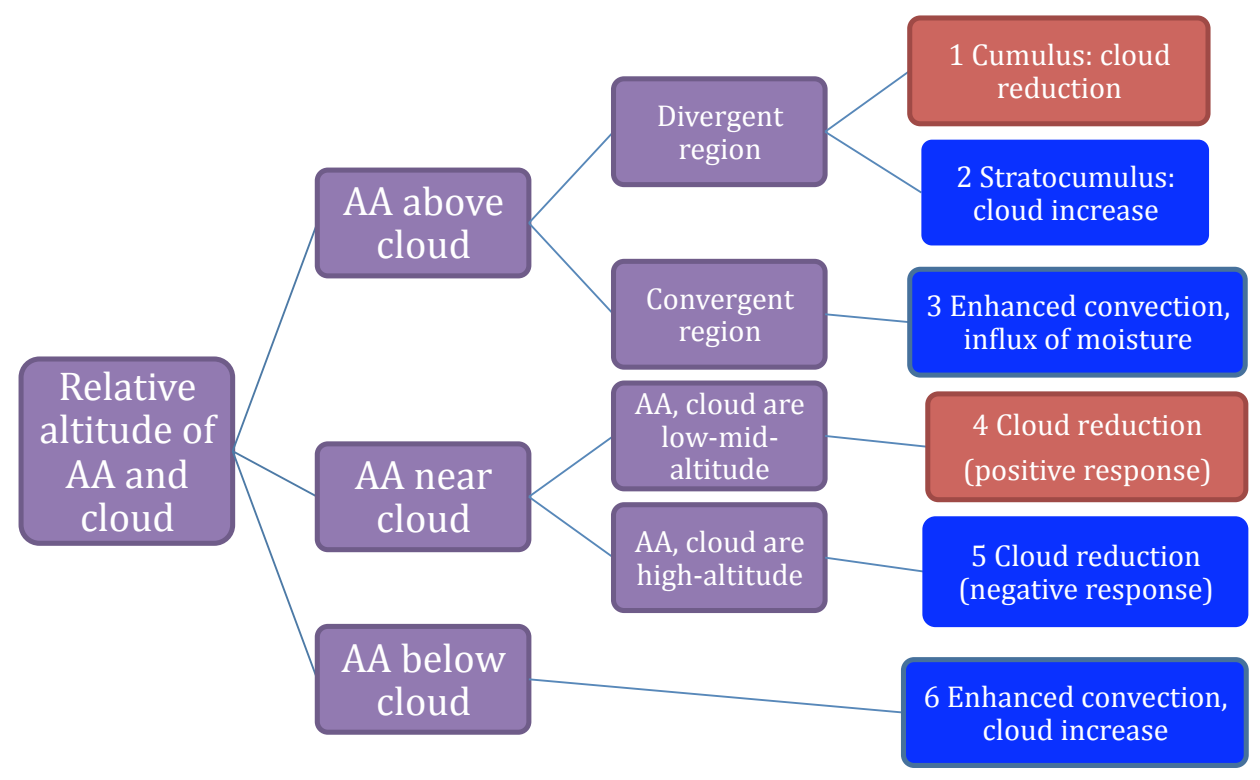

Fig. 1. Suggested framework to organize aerosol absorption effects on cloud cover. Red and blue indicate positive and negative semi-direct effects.

note that global models do not simulate stratocumulus clouds well and may therefore inadequately reproduce these effects. The study also demonstrated very little cloud change for scattering aerosols above cloud.

Brioude et al. (2009) presented a field example of biomass burning smoke over marine stratocumulus off the coast of California in summertime (see Table 1). They analyzed cloud data from the Geostationary Operational Environmental Satellite (GOES) and Moderate resolution Imaging Spectrometer (MODIS), and derived biomass burning aerosol using a passive biomass burning tracer in the FLEXPART model. They found that biomass burning aerosols enhanced cloud cover, especially for high-humidity conditions and for low lower tropospheric stability (LTS) conditions, since the aerosols have the effect of increasing LTS. Greater LTS decreases vertical entrainment of dry air from above, increasing boundary layer (BL) relative humidity. Most of the region had AAs above the BL and increased cloud cover. However farther from the continent, at the edge of the study domain, AAs occurred within the BL and were associated with decreased cloud cover.

\subsection{AA above cumulus clouds}

While the stabilizing effect of AAs aloft can enhance stratocumulus cloud cover as shown in Sect. 3.2, other studies show that they may on the other hand suppress cumulus cloud development. Over land, the AAs may also reduce evaporation from the surface and therefore moisture available for cloud formation, as has been demonstrated in the following studies.
Fan et al. (2008) simulated cloud reduction by AAs in Houston in August due mostly to the stabilizing effects of the AAs (see Table 1). They used a two-dimensional cloudresolving Goddard Cloud Ensemble model with spectral-bin cloud microphysics coupled to a land-surface model. The aerosols cooled the surface, increasing underlying relative humidity, but the heating aloft decreased the relative humidity there. The heating decreased the temperature lapse rate, leading to a more stable atmosphere, and decreased convection. Decreased precipitation also resulted from the shallower clouds. Compared to a simulation with no aerosols, cloud fraction and cloud optical depth decreased by about 20\%; LWP, IWP and precipitation also decreased. The semi-direct effect was about $10 \mathrm{Wm}^{-2}$, and the direct effect $2.2 \mathrm{Wm}^{-2}$. For another similar experiment with scattering aerosols, there was minimal cloud change.

Koren et al. (2004, 2008) conducted MODIS observational studies for the biomass burning season of the Amazon that also demonstrated cumulus cloud cover reduction due to increased smoke (see Table 1). They argued that the smoke plumes stabilized the BL, reducing convective activity and BL cloud formation. The smoke also reduced radiation penetration to the canopy, therefore decreasing evapotranspiration, an important source of moisture in this region. In addition, the smoke particles may compete for available moisture, decreasing the ability of the air to reach supersaturation. Koren et al. (2008) reported a transition from smoke enhancement of cloud cover at low aerosol optical depth (AOD), which they argued was microphysical invigoration, to smoke radiative reduction of cloud cover as AOD increased. They also showed that cloud inhibition due to radiative absorption effects was stronger for smaller initial cloud cover. 
Table 1. Summary of studies that provide semi-direct effect estimates, organized by study type (Observational, cloud-scale model, global model, etc.) and then alphabetically.

\begin{tabular}{|c|c|c|c|c|c|c|c|c|}
\hline Study & $\begin{array}{l}\text { Regime Fig. } \\
1(1)\end{array}$ & $\begin{array}{l}\text { Region, cloud } \\
\text { type }\end{array}$ & $\begin{array}{l}\text { Semi-direct ef- } \\
\text { fect } \mathrm{Wm}^{-2}(2)\end{array}$ & $\begin{array}{l}\text { Cloud cover } \\
\text { change }(\%)\end{array}$ & $\begin{array}{l}\text { Species, optical } \\
\text { properties varied } \\
\text { (3) }\end{array}$ & $\begin{array}{l}\text { Model ef- } \\
\text { fects (4) }\end{array}$ & $\begin{array}{l}\text { Model or obs; SD effect calcula- } \\
\text { tion method (5); initial conditions } \\
\text { (6) }\end{array}$ & Comments \\
\hline \multicolumn{9}{|l|}{ Observational } \\
\hline Brioude et al., 2009 & 2 & $\begin{array}{l}\text { Marine stra- } \\
\text { tocumulus }\end{array}$ & $T=-7.5 \%$ & $\begin{array}{l}+0.14 \text { frac- } \\
\text { tion }\end{array}$ & $\begin{array}{l}\text { Biomass burning } \\
\text { aerosols }\end{array}$ & & $\begin{array}{l}\text { GOES, MODIS observations. } \\
\text { Flexpart model; concentration = } \\
6 \mathrm{mg} \mathrm{m}^{-3}(\mathrm{~B})\end{array}$ & $\begin{array}{l}\text { Regime with biomass burning } \\
\text { above cloud level. }\end{array}$ \\
\hline Koren et al., 2004 & 1 & $\begin{array}{l}\text { Amazon, } \\
\text { dry season, } \\
\text { cumulus }\end{array}$ & $\begin{array}{l}T=+8 \\
\text { (aerosol and } \\
\text { cloud) } \\
T_{c}=+36 \\
\text { (cloud only) }\end{array}$ & -38 & $\begin{array}{l}\mathrm{AOD}=1.3 \quad \text { vs. } \\
\mathrm{AOD}=0.1 \\
\mathrm{SSA}=0.91\end{array}$ & & MODIS observations (C) & \\
\hline \multicolumn{9}{|l|}{ LES/Cloud-resolving models } \\
\hline Ackerman et al., 2000 & 4 & $\begin{array}{l}\text { Indian Ocean, } \\
\text { trade cumu- } \\
\text { lus }\end{array}$ & $\begin{array}{l}T_{c}=+3.7 \\
S_{c}=-2.8\end{array}$ & -25 & $\begin{array}{l}\mathrm{AAOD}=0.024 \\
\mathrm{SSA}=0.88\end{array}$ & $\mathrm{SD}(\mathrm{DE})$ & $\begin{array}{l}\text { LES model; } \\
N=1200 \mathrm{~cm}^{-3} \\
\text { (A) }\end{array}$ & $\begin{array}{l}\text { Difference between scattering } \\
\text { (base) and INDOEX } 1998\end{array}$ \\
\hline \multirow[t]{2}{*}{ Fan et al., 2008} & 1 & \multirow[t]{2}{*}{$\begin{array}{l}\text { Texas, deep } \\
\text { convection }\end{array}$} & \multirow[t]{2}{*}{$\begin{array}{l}T=+10 \\
S=+11.2\end{array}$} & -18 & $\begin{array}{l}\text { AAOD }=0.04 \\
\text { SSA }=0.85\end{array}$ & \multirow[t]{2}{*}{$\mathrm{SD}(\mathrm{DE}, \mathrm{IE})$} & \multirow[t]{2}{*}{$\begin{array}{l}\text { 2-D cloud resolving model; } \\
N=4.2 \times 10^{4} \mathrm{~cm}^{-3} \text { (B) }\end{array}$} & $\begin{array}{l}\text { Absorbing aerosol aloft, Exp } \\
\text { AR_85 }\end{array}$ \\
\hline & $S$ & & & 0 & $\begin{array}{l}\mathrm{SSA}=1 ., \\
\mathrm{AOD}=0.25\end{array}$ & & & $\begin{array}{l}\text { Scattering aerosol, Exp } \\
\text { SA_100 }\end{array}$ \\
\hline \multirow[t]{2}{*}{ Feingold et al., 2005} & 4 & \multirow[t]{2}{*}{$\begin{array}{l}\text { Amazon, } \\
\text { September }\end{array}$} & & -5 & \multirow[t]{2}{*}{ SSA $=0.9$} & \multirow[t]{2}{*}{$\mathrm{SD}(\mathrm{DE})$} & \multirow[t]{2}{*}{$\begin{array}{l}\text { LES model, } \\
N=5000 \mathrm{~cm}^{-3} \text {; } \\
\text { (A) }\end{array}$} & Aerosol in cloud \\
\hline & 6 & & $\begin{array}{l}S=-40 \text { to } \\
-100\end{array}$ & $\begin{array}{l}0 \\
+\mathrm{LWP}\end{array}$ & & & & Aerosol below cloud \\
\hline Hill \& Dobbie, 2008 & 4 & $\begin{array}{l}\text { Marine stra- } \\
\text { tocumulus }\end{array}$ & $\begin{array}{l}T=+11 \\
S=+12\end{array}$ & - & SSA $=0.9$ & $\begin{array}{l}\text { SD } \\
\text { (DE, IE) }\end{array}$ & $\begin{array}{l}\text { LES model; } \mathrm{CCN}=600 \mathrm{~cm}^{-3} \text {; ef- } \\
\text { fect increases with CCN; (B) }\end{array}$ & $\begin{array}{l}\text { Difference between run with } \\
\text { and without SD }\end{array}$ \\
\hline \multirow[t]{3}{*}{ Johnson et al. 2004} & 4 & \multirow[t]{3}{*}{$\begin{array}{l}\text { Subtropical } \\
\text { marine stra- } \\
\text { tocumulus }\end{array}$} & $T=+14$ & - & $\begin{array}{l}\mathrm{SSA}=0.88 \\
\mathrm{AAOD}=0.018\end{array}$ & \multirow[t]{3}{*}{$\mathrm{SD}(\mathrm{DE})$} & \multirow[t]{3}{*}{$\begin{array}{l}\text { LES model; } \\
\text { Aerosol mass mixing } \\
\text { ratio }=3 \times 10^{-8} \mathrm{~kg} / \mathrm{kg}(\mathrm{B})\end{array}$} & Aerosol in cloud (Exp 1-088) \\
\hline & 2 & & $T=-9.5$ & + & $\begin{array}{l}\text { SSA }=0.88 \\
\text { AAOD }=0.024\end{array}$ & & & $\begin{array}{l}\text { Aerosol above cloud (Exp 2- } \\
\text { FT) }\end{array}$ \\
\hline & $\mathrm{S}$ & & $T=-0.1$ & 0 & $\mathrm{SSA}=1$ & & & $\begin{array}{l}\text { Scattering aerosol above cloud } \\
\text { layer (Exp 2-FTS) }\end{array}$ \\
\hline \multirow[t]{2}{*}{ McFarquhar \& Wang, 2006} & 4 & \multirow[t]{2}{*}{$\begin{array}{l}\text { Indian Ocean, } \\
\text { trade cumu- } \\
\text { lus }\end{array}$} & $\begin{array}{l}T=+1.3 \\
S=+1.6\end{array}$ & - & \multirow[t]{2}{*}{$\mathrm{SSA}=0.89$} & \multirow[t]{2}{*}{$\mathrm{SD}(\mathrm{DE})$} & \multirow[t]{2}{*}{$\begin{array}{l}\text { 3D Eulerian cloud resolving } \\
\text { model; } \mathrm{CDNC}=350 \mathrm{~cm}^{-3}(\mathrm{~B})\end{array}$} & Aerosols in-cloud \\
\hline & 6 & & $\begin{array}{l}T=-0.6 \\
S=-0.4\end{array}$ & + & & & & Aerosols below cloud \\
\hline \multicolumn{9}{|c|}{ Global model study with regional focus } \\
\hline \multirow[t]{2}{*}{$\begin{array}{l}\text { Randles \& Ramaswamy } \\
2008\end{array}$} & 3 & \multirow[t]{2}{*}{$\begin{array}{l}\text { Global } \\
\text { model, re- } \\
\text { sults over } \\
\text { China }\end{array}$} & & +3.1 & $\begin{array}{l}\mathrm{AAOD}=0.083 \\
\mathrm{AOD}=1.2\end{array}$ & \multirow[t]{2}{*}{$\mathrm{SD}(\mathrm{DE})$} & \multirow[t]{2}{*}{$\begin{array}{l}\text { Cloud changes are over China for } \\
\text { JJA, compared to Exp BASE with } \\
\text { AAOD }=0.015, \text { AOD }=0.15\end{array}$} & Expt XCh \\
\hline & $S$ & & & -1.2 & $\begin{array}{l}\mathrm{AAOD}=0.008 \\
\mathrm{AOD}=1.1\end{array}$ & & & Expt XChW \\
\hline \multicolumn{9}{|c|}{ Global model studies with global semi-direct estimates } \\
\hline \multirow[t]{2}{*}{ Penner et al., 2003} & \multirow[t]{2}{*}{$5, V$} & \multirow[t]{2}{*}{ Global model } & $T=-0.36$ & $\begin{array}{l}\text {-(high } \\
\text { cloud loss) }\end{array}$ & $\begin{array}{l}\mathrm{BC}+\mathrm{OC}, \quad \text { burden } \\
(\mathrm{Tg}): \Delta \mathrm{BC}=0.11 \\
\Delta \mathrm{OC}=2.52\end{array}$ & \multirow[t]{2}{*}{$\mathrm{SD}(\mathrm{DE})$} & \multirow[t]{2}{*}{ (D) } & $\begin{array}{l}\text { Biomass burning } \\
\text { Standard deviation is } 0.47\end{array}$ \\
\hline & & & $T=-0.09$ & & $\begin{array}{l}\mathrm{BC}+\mathrm{OC} \\
\text { Burden } \\
\Delta \mathrm{BC}=0.09 \quad(\mathrm{Tg}): \\
\Delta \mathrm{OC}=0.42\end{array}$ & & & $\begin{array}{l}\text { Fossil fuel } \\
\text { Standard deviation is } 0.39\end{array}$ \\
\hline Perlwitz \& Miller, 2010 & V & Global model & & +0.58 & $\mathrm{AAOD}=0.012$ & $\mathrm{SD}(\mathrm{DE})$ & $\begin{array}{l}\text { Cloud changes are low cloud, for } \\
\text { dust vs. no-dust, average of DJF } \\
\text { and JJA. }\end{array}$ & $\begin{array}{l}\text { Case SSAx0.8 (absorbing } \\
\text { dust) }\end{array}$ \\
\hline & & & & +0.02 & $\mathrm{SSA}=1$ & & & $\begin{array}{l}\text { Case SSAx1.1 (scattering } \\
\text { dust) }\end{array}$ \\
\hline Wang 2004 & V & Global model & $\begin{array}{l}T=-0.16 \\
S=-0.17\end{array}$ & +0.18 & $\mathrm{BC}$ & $\mathrm{SD}(\mathrm{DE})$ & $\begin{array}{l}\text { Cloud changes are low-cloud } \\
\text { with } B C \text { vs without } B C(B)\end{array}$ & $\begin{array}{l}\text { TOA flux difference has stan- } \\
\text { dard deviation of } 0.3\end{array}$ \\
\hline
\end{tabular}


Table 1. Continued.

\begin{tabular}{|c|c|c|c|c|c|c|c|c|}
\hline Study & $\begin{array}{l}\text { Regime Fig. } \\
1(1)\end{array}$ & $\begin{array}{l}\text { Region, cloud } \\
\text { type }\end{array}$ & $\begin{array}{l}\text { Semi-direct ef- } \\
\text { fect } \mathrm{Wm}^{-2}(2)\end{array}$ & $\begin{array}{l}\text { Cloud cover } \\
\text { change }(\%)\end{array}$ & $\begin{array}{l}\text { Species, optical } \\
\text { properties varied } \\
\text { (3) }\end{array}$ & $\begin{array}{l}\text { Model ef- } \\
\text { fects (4) }\end{array}$ & $\begin{array}{l}\text { Model or obs; SD effect calcula- } \\
\text { tion method (5); initial conditions } \\
\text { (6) }\end{array}$ & Comments \\
\hline \multicolumn{9}{|c|}{ Global models with semi-direct effect inferred from BC efficacy } \\
\hline Chung \& Seinfeld, 2005 & $\mathrm{~V}$ & Global model & $\begin{array}{l}T=-0.10 \\
F=0.33 \\
E=0.70\end{array}$ & & $\begin{array}{l}\Delta \mathrm{BC} \text { burden }= \\
0.13 \mathrm{Tg} \\
\Delta \mathrm{BCgemission}= \\
10.6 \mathrm{Tg}\end{array}$ & & (E) & $\mathrm{BC}(\mathrm{PD}-\mathrm{PI})$ \\
\hline Jones et al., 2007 & $\mathrm{~V}$ & Global model & $\begin{array}{l}T=-0.11 \\
F=0.39 \\
E=0.71\end{array}$ & & $\begin{array}{l}\Delta \mathrm{BC} \text { emission }= \\
7.3 \mathrm{Tg}\end{array}$ & & (E) & $\mathrm{BC}(\mathrm{PD}-\mathrm{PI})$ \\
\hline \multirow[t]{2}{*}{ Hansen et al. 2005} & $\mathrm{~V}$ & Global model & $\begin{array}{l}T=-0.08 \\
F=0.19 \\
E=0.58\end{array}$ & & BC AAOD $=0.0025$ & & \multirow[t]{2}{*}{$\begin{array}{l}\text { AAOD from Sato et al. (2003) } \\
\text { partitioned by BC AOD to } \\
\text { biomass burning and fossil fuel. } \\
\text { (E) }\end{array}$} & Biomass burning $\mathrm{BC}$ \\
\hline & & & $\begin{array}{l}T=-0.11 \\
F=0.49 \\
E=0.78\end{array}$ & & BC AAOD $=0.0038$ & & & Fossil fuel BC \\
\hline $\begin{array}{l}\text { Yoshimori \& Broccoli } \\
\text { (2008) }\end{array}$ & $\mathrm{V}$ & Global model & $\begin{array}{l}T=-0.4 \\
F=0.99 \\
E=0.59\end{array}$ & $\begin{array}{l}\text {-(mid-high) } \\
\text { +low }\end{array}$ & BC only & & (E) & $1.6 \times(\mathrm{PD}-\mathrm{PI}) \mathrm{BC}$ \\
\hline
\end{tabular}

(1) Numbers (1) to (6) correspond to Fig. 1; $S=$ sensitivity study using scattering aerosols, $V=$ various effects in global model;

(2) $T$ =semi-direct effect at TOA; $\mathrm{S}=$ semi-direct effect at surface; $F=\mathrm{BC}$ forcing; $\mathrm{E}=$ efficacy; $c=$ cloudy-sky;

(3) $\mathrm{AOD}=$ aerosol optical depth; AAOD=aerosol absorption optical depth; SSA=single scattering albedo;

(4) $\mathrm{SD}=$ semi-direct effect, $\mathrm{DE}=$ direct effect, $\mathrm{IE}=$ indirect effect; effects included in model but not in semi-direct effect diagnostic are in parentheses;

(5) Initial conditions: $N=$ aerosol particle number, $\mathrm{CCN}=$ cloud condensation nuclei, $\mathrm{CDNC}=$ cloud droplet number concentration;

(6) Method used to calculate semi-direct effect (in column 5):

A Change in radiative flux for absorbing vs scattering aerosols

B Change in radiative flux between SD+D and D; D is typically based on cloud-free region

C Change in radiative flux between polluted and clean conditions (includes clouds and aerosols)

D Difference between relaxed and instantaneous forcing

E Inferred from climate forcing and model efficacy.

\section{Enhanced low-level convergence over land regions}

Several studies have described increases in clouds and/or precipitation in regions where lofted AAs have enhanced upper level convective activity, arguing that this has promoted larger scale circulation with enhanced low-level convergence carrying in moist air. In many cases the studies describe reductions in moisture or cloud cover in adjacent regions, so that overall cloud cover change may not occur. This has been studied in three regions: Africa, south Asia and Southeast Asia. Most of the studies have been performed with global models since only in such models can the large scale circulation respond to changes in AAs; however the studies focus on particular regional changes.

Over Africa, Stephens et al. (2004) used a 2-D cloudresolving model to study the effect of a lofted dust layer on tropical convection for either dry or moist atmospheric conditions. The experiments with lofted dust produced lowlevel convergent flow toward the dust region and enhanced convection. The non-dusty adjacent regions experienced reduced convection. The enhanced convection was greater for an experiment with moist mid-troposphere conditions compared to one initialized in a drier atmosphere, demonstrating the importance of entrainment mixing for convective development.
Miller et al. (2004) also focused on dust effects on clouds in Africa, in the Western Sahara. They used the GISS climate model and found that dust loading caused increased low-level cloud cover and precipitation. They argued that in an arid region, where diabatic heating is overwhelmed by longwave cooling and is balanced by subsidence, dust absorption in an aerosol layer aloft could reverse the circulation, resulting in ascent and precipitation.

Rudich et al. (2003) analyzed AVHRR satellite observations of smoke and clouds from the Kuwait oil fires of March 2001. They found that the absorbing aerosols in the heaviest smoke plumes cooled the underlying surface, but heated the plume and induced convective clouds above the layer of the smoke plume.

Several studies have considered the effects of AAs on the South Asian monsoon. Lau et al. (2006) used the NASA GSFC finite volume GCM with aerosol optical depth from the GOCART model to study dust and black carbon effects on the Indian monsoon. They showed that pre-monsoon lofted dust accumulates beside the Tibetan Plateau and creates an elevated heat pump that draws in moisture from the Indian Ocean. Black carbon pollution may contribute to intensification of the Indian monsoon and the sea level pressure anomaly pattern, with consequent weakening of the East Asian monsoon. 
A similar result was obtained by Randles and Ramaswamy (2008) using the GFDL GCM with offline aerosols from MOZART-2 and fixed SSTs (see Table 1). They found that for sufficiently large aerosol extinction optical depths, cloud amount increased as absorption increased. The aerosols warmed the atmosphere but cooled the surface and reduced latent and sensible heat fluxes. Low-level convergence and increased vertical velocity overcame the stabilization effects of the aerosols so that monsoon circulation and precipitation were enhanced over northwestern India. An experiment with scattering aerosols resulted in cloud loss in the region.

Chung et al. (2002) also modeled the INDOEX region, with the NCAR CCM3 and fixed SSTs. They found that pollution haze cooled the land surface, warmed the atmosphere, stabilized the boundary layer, and reduced evaporation and sensible heat flux from the land. The warming also weakened the north-south temperature gradient and caused a northward shift of the Inter-Tropical Convergence Zone (ITCZ). This resulted in enhanced convective precipitation, latent heat release, and a further increase in convergence. The shift in precipitation also caused reduced rainfall in adjacent regions, such as southwest Asia. Decreased evaporation over the oceans from the haze caused decreased precipitation over the rest of the Tropics.

However, Ramanathan et al. (2005) found a different impact of AAs on the south Asian monsoon, using the NCAR coupled ocean-atmosphere model and transient simulations from 1930 to 2000. Observed pollution levels for the wintertime Indian Ocean experiment were applied and absorbing aerosols followed emission trends scaled to observed present-day levels. As in the previous studies, they found that the AAs in the region reduced surface radiation, surface temperatures, evaporation from the surface and rainfall. The reduced evaporation resulted from the reduction in vertical temperature gradient (warming aerosols aloft and cooling at the surface), which inhibited convection, increasing relative humidity near the surface but decreasing relative humidity aloft; the higher relative humidity near the surface reduced evaporation. The aerosols over northern India reduced the meridional temperature gradient and in this study, weakened the monsoon. Little change in cloud cover occurred in the simulations. Compared with the other studies in this region, this model was coupled to an ocean and therefore SSTs responded to cloud and aerosol changes. It also focused on wintertime BC advected from India over the Indian Ocean while the work of Lau et al. (2006) focused on premonsoon dust effects in northern India. Even though Ramanathan et al. (2005) found reduced precipitation in south Asia, a follow-up study by Chung and Ramanathan (2006) showed that the weakened SST gradient and meridional circulation also resulted in enhanced precipitation over subSaharan Africa. This second study also confirmed some of the results of other models for the region, that AAs in Southeast Asia cause diabatic warming, upwelling and enhanced precipitation locally; however this effect was overwhelmed by the SST gradient effect that weakened the monsoon in India.

In general these studies on the Indian monsoon region focused more on changes in precipitation rather than cloud cover. However Norris (2001) analyzed surface-based cloud cover observations and found an increasing trend in low-level cloud cover in the Indian Ocean during January to April from 1952 to 1996 . The mechanism for this increase however was not apparent.

In the Southeast Asian region, Menon et al. (2002) used the GISS GCM with fixed SSTs to see how regional AAs having single scattering albedo of 0.85 affect that region's climate. They found that the region with greatest pollution had enhanced convective upwelling, increased precipitation and increased cloud cover. The precipitation changes in southern China agree with observations while the enhanced cloud cover apparently does not. Zhang et al. (2009) performed a similar experiment with carbonaceous aerosols in the NCAR CAM3 model and obtained opposite results for the regional distribution of rain and cloud. It is not clear how the single scattering albedo or vertical distribution of the aerosols compare in these studies.

To some extent the conflicting results from different global models for particular regions may result from natural variability within their noisy climate systems as well as differences in their general cloud responses to forcing changes as discussed below.

\section{Summary of regional variations in cloud response to AAs}

On the basis of the studies on cloud responses to AAs that have focused on particular regions, we propose a straw-man framework for classifying the range of possible semi-direct effects, provided in Fig. 1. This framework must be considered tentative, since no single model has systematically explored the effects of AAs at different altitudes, in different regions, or under different environmental conditions, and structural differences among models may lead to different cloud responses to the same AA forcing.

For one mechanism, AAs embedded within cloud layers or potential cloud layers reduce cloud cover due to their heating and reduction of relative humidity (case 4 in Fig. 1). For many studies, the altitude of AAs relative to a cloud or potential cloud layer seems to play a critical role in determining the cloud response. AAs below cloud may promote convective activity and enhance cloud cover (case 6). AAs aloft tend to stabilize the boundary layer and may promote cloud cover for some conditions such as for marine stratocumulus as they stabilize the boundary layer and reduce mixing with dry air above (e.g. Johnson et al., 2004; Brioude et al., 2009; case 2). However AAs over shallow cumulus clouds can instead inhibit cloud development (e.g. Koren et al., 2004) as they stabilize the surface layer and reduce surface evaporation and 
stabilize the lapse rate near cloud top, inhibiting further rising motion (case 1). On the other hand, in some land regions, lofted AAs may enhance upper level convection, promoting low-level convergence that could carry moisture toward cloud base and increase clouds (case 3 ). An additional case is the reduction of high-level clouds found in some global models and is discussed below (case 5); this would also cause a negative cloud feedback.

\section{Global impacts of AA on clouds}

Considering the results of the regional studies, with AAs leading to cloud cover increase for some conditions but decrease for others, it is not surprising that global model studies find both cloud reduction and enhancement depending on the region. Here we discuss studies that have presented net global cloud response.

The global BC model study of Wang (2004) found that the net cloud-cover change caused by $\mathrm{BC}$ was positive (see Table 1). This study included both Qflux climate and fixed SST simulations, using the CSM-NCAR model, both with and without BC. (In a Qflux climate experiment, ocean temperature response to changes in the surface energy balance is approximated by including an energetic adjustment in a slab ocean layer without allowing ocean heat transports to change.) The $\mathrm{BC}$ effects on clouds were much stronger for the Qflux simulations. BC enhanced convective activity and cloud cover in the northern branch of the ITCZ, with smaller magnitude of reduction in clouds and convective activity in the Southern Hemisphere. The enhancement was espeically large in the Pacific and over India. Significant changes were also found for precipitation, meridional heat transport, surface heat fluxes and boundary layer height. He found a much larger reduction in surface radiation for the Qflux simulation due mostly to increased low-level cloud cover. The Qflux cloud forcing change, the difference between all-sky and clear-sky radiative flux change due to $\mathrm{BC}$, was $-0.16 \mathrm{Wm}^{-2}$ at the top-of-atmosphere, and $-0.17 \mathrm{Wm}^{-2}$ at the surface. Furthermore, the top-of-atmosphere $\mathrm{BC}$ all-sky forcing was $30 \%$ less, or $-0.10 \mathrm{Wm}^{-2}$ smaller for the Qflux simulation compared with the fixed SST simulation. The cloud cover changes varied greatly with region, with increased cloud occurring, e.g., over northern Eurasia as well as the northern branch of the ITCZ mentioned above. Overall, BC was not found to cause significant warming in the climate change experiments apparently due to compensatory cloud-cover and hydrological changes.

Roeckner et al. (2006) performed transient climate simulations in the ECHAM5 model, beginning in the 20th century and going to 2050. The experiments included direct and indirect effects as well as semi-direct effects. Two futures beyond year 2000 were considered. The first had increased carbonaceous aerosol emissions (37\% BC and 25\% particulate organic matter) using an SRES A1B estimate; the second had no change in carbonaceous aerosol emissions after year 2000. For the A1B, carbonaceous aerosols decreased from Europe and China but increased in many low-latitude regions, especially African biomass burning regions. Similar to Wang (2004), A1B did not warm compared with the control, and actually cooled in regions where the aerosols increased strongly, such as the African biomass burning region, the Indian subcontinent and the Atlantic Ocean biomass burning outflow region. Hydrologic changes were strong in these regions, with enhanced precipitation, increased soil moisture, and increased liquid water path over India and Africa. Over the Atlantic Ocean off the coast of Africa, increased cloud cover and liquid water path also occurred as AAs above the boundary layer stabilized the boundary layer and cooled the surface. Roeckner et al. (2006) noted that these hydrological changes are more likely in a future warming climate and are not necessarily expected for 20th century conditions. We note that the experiments included changes to organic as well as black carbon, and to indirect as well as semi-direct and direct effects; these could also contribute to the cloud cover enhancement.

In a GISS climate model investigation, Perlwitz and Miller (2010) studied how dust affects cloud cover (see Table 1). These experiments used a slab ocean and dust with varying optical properties. They showed that for sufficiently large dust AOD and absorption, the net effect is enhanced cloud cover for all seasons except winter. Cloud cover decreased over Eurasia, western North America and South America. The largest cloud cover enhancement occurred over oceans, central Africa, the Arabian peninsula, India and southeastern Asia. Over land, cloud cover increased where the absorbing dust enhanced specific humidity due to increased moisture convergence driven by the dust heating. Overall this effect exceeded the reduced humidity that results from dust absorption enhancing atmospheric evaporation. For scattering (low absorption) dust, for small dust AOD, and for winter conditions, the cloud cover enhancement responses were weak or even reversed.

Allen and Sherwood (2010) found a net $+0.1 \mathrm{Wm}^{-2}$ positive semi-direct effect from all aerosols (carbonaceous and sulfate) in another study using the NCAR CAM3 model with mixed-layer ocean. In this study both scattering and absorbing aerosols were prescribed from Chung et al. (2002) and aerosol heating was uniformly placed in the lowest 3 kilometers of the model. The study found a strong landsea contrast in cloud response, with increased cloud cover over oceans and cloud loss over land, mostly at mid-level. Over land the dominant aerosol effect was reduction of relative humidity, while over oceans the aerosol stabilization of the boundary layer tended to enhance cloud cover. The GCM used here was the same as in Wang (2004), however here the aerosols were much less absorbing and were confined to the lower troposphere, which may explain the different net cloud response. 
Some global model studies report reduction of upper level clouds due to lofted AA. The resulting climate forcing is also negative. Presumably this results from cloud burn-off or from reduction of relative humidity at high altitudes, associated with lofted AA.

For example, Penner et al. (2003) found a net negative forcing cloud response to carbonaceous aerosols (both organic and black carbon) in the GRANTOUR GCM due mostly to loss of high-level clouds (see Table 1). They calculated climate forcing by taking the difference between relaxed forcing, or forcing change taken at TOA averaged over the simulation, and the instantaneous TOA radiative forcing; the former includes the cloud response while the latter does not. They found that aerosols injected at mid-tropospheric levels enhanced low-level and also reduced upper-level cloud cover, with both contributing to a negative cloud-radiative effect. The radiative cloud effect due to biomass burning aerosols was $-0.37 \mathrm{Wm}^{-2}$ in the experiments, with small response for non-biomass burning aerosols. Aerosols injected near the surface, on the other hand, reduced cloudiness.

Roberts and Jones (2004) performed Qflux climate experiments in the Hadley Centre Climate model, isolating the effects of $\mathrm{BC}$ on climate. They found the climate sensitivity of $\mathrm{BC}$ to be less $(62 \%)$ than for $\mathrm{CO}_{2}$. The reason seemed to be reduction in high-altitude clouds caused by BC. Although not discussed in their paper, their Figure 8a also suggests an increase in low-level clouds due to BC.

Menon and Del Genio (2007) also report a negative BC semi-direct effect of $-0.08 \mathrm{Wm}^{-2}$ in their (fixed SST) GISS simulations due to decreased long-wave cloud feedback associated with loss of high-level clouds mostly in biomass burning regions.

There are several global climate model studies that have reported $\mathrm{BC}$ efficacy, or the temperature change per unit forcing relative to that for $\mathrm{CO}_{2}$, less than 1 (see Table 1). In some cases the studies indicate that cloud changes are responsible for the low efficacy. Hansen et al. (2005) showed that BC efficacy decreases with higher BC altitude in the GISS model. They argued that low-altitude $\mathrm{BC}$ reduces cloud cover, however $\mathrm{BC}$ above the boundary layer inhibits underlying convection and therefore enhances large scale cloud cover. This cloud enhancement greatly reduces the warming direct effect of the BC. Yoshimori and Broccoli (2008) also found BC efficacy less than 1 due to negative cloud response because $\mathrm{BC}$ caused increased low-level cloud cover especially at high latitudes of the Northern Hemisphere, but decreased mid-upper level cloud cover. In additional BC experiments they found that increasing the $\mathrm{BC}$ forcing did not change the efficacy, however placing the $\mathrm{BC}$ at lower altitudes increased the efficacy, consistent with the results from Hansen et al. (2005).

If we assume, as an upper limit, that the reduced BC efficacy is due to cloud cover changes, we may infer maximum BC semi-direct estimates for these models (see Table 1). Hansen et al. (2005) found BC efficacy of 0.78 for fossil fuel $\mathrm{BC}$ and 0.58 for biomass burning $\mathrm{BC}$ for forcings of
$0.49 \mathrm{Wm}^{-2}$ and $0.1 \mathrm{Wm}^{-2}$. If the reduced efficacy were due to cloud changes, the cloud forcing changes are -0.11 and $-0.08 \mathrm{Wm}^{-2}$ respectively. Yoshimori and Broccoli (2008) had efficacy of 0.59 for BC forcing of $0.99 \mathrm{Wm}^{-2}$ giving a maximum cloud forcing change of $-0.4 \mathrm{Wm}^{-2}$. Jones et al. (2007) report a BC efficacy of 0.71 for BC forcing of $0.39 \mathrm{Wm}^{-2}$, leading to inferred upper-limit semi-direct effect of $-0.11 \mathrm{Wm}^{-2}$. Chung and Seinfeld calculated a 0.70 efficacy for $0.33 \mathrm{Wm}^{-2}$ forcing, giving a $-0.10 \mathrm{Wm}^{-2}$ upper limit cloud response. From these we estimate a range of -0.1 to $-0.4 \mathrm{Wm}^{-2}$ for the $\mathrm{BC}$ cloud semi-direct effect. However we note that the absorption optical depths are not always provided by these studies but could differ by as much as a factor of three among global models (Schulz et al., 2006), with semi-direct effect increasing and efficacy decreasing with AAOD. Also, BC efficacy reduction may be caused by various factors in addition to cloud changes, so that this method of extracting cloud response from efficacy and $\mathrm{BC}$ forcing is qualitative.

\section{Discussion}

We have considered several mechanisms by which absorbing aerosols may either increase or decrease cloud cover. Although the "semi-direct" effect was originally defined as reduction of clouds due to increased evaporation with resulting positive climate forcing, there are many studies describing cloud-cover increase from absorbing aerosols and negative cloud feedback. Global model studies have both enhanced and decreased cloud cover depending on region and conditions. Therefore there appear to be not one, but several semidirect effects.

Table 1 summarizes most of the studies with semi-direct effect estimates discussed here. The experiments and diagnostics provided in each case are very diverse. Nevertheless, we have constructed a tentative framework to organize the previous research on the semi-direct effects, illustrated in Fig. 1. The framework rests on a relatively small number of studies (e.g. in column 1 of Table 1), to be extended and improved as more research warrants. According to the studies we have examined, the sign of the cloud change seems to depend on several factors. First is the altitude of the AAs relative to the cloud or potential cloud level. For AAs within the cloud layer, absorptive heating can burn off the clouds and moisture. AAs below cloud level can enhance convective activity and increase cloud cover. AAs above cloud-level stabilize the underlying layer and can result in either decreased or increased cloud depending on cloud type and underlying conditions. AAs above stratocumulus clouds tend to enhance cloud cover. AAs above shallow cumulus in oceanic regions might also strengthen the inversion and promote transition to a stratocumulus regime with increased cloud cover (e.g. Stevens et al., 2001), although this has not been demonstrated in the AA-cloud studies presented here. Since AAs are derived from land-sources and are lofted before transport over 
the oceans, they tend to reside above cloud level over oceans and would therefore typically promote clouds. However for AAs above low cumulus clouds over land, the enhanced stability can reduce convective cloud formation. Over land the AA's blocking of incoming solar radiation also reduces surface evaporation that can reduce moisture available for cloud formation. Finally, AAs advected into a convergent region can enhance deep convection and low-level convergence, potentially drawing in moist air from oceanic regions. An additional effect found in some global model studies is reduction of upper-level clouds, especially due to lofted biomass burning aerosols. This is apparently due to decreased upper-level humidity and/or cloud burn-off (e.g. Penner et al., 2003). Because the clouds are high-altitude the radiative effect is negative.

The cloud response to AAs also depends upon the aerosol optical properties. The AOD must be sufficiently large, and the cloud response increases for lower single scattering albedo, i.e. for more absorbing particles. Several studies demonstrated that scattering aerosols reduced or even slightly reversed the semi-direct effect (e.g. Johnson et al., 2004; Fan et al., 2008; Randles and Ramaswamy, 2008; Perlwitz and Miller, 2010; Wang, 2004). Therefore some of the studies that considered carbonaceous aerosols (e.g. Penner et al., 2003) or all aerosols (e.g. Allen and Sherwood, 2010) are expected to have smaller semi-direct effect than those that isolate BC. Note that most of the cloud-scale models discussed here specified the aerosol optical properties, such as single scattering albedo and AOD, to be appropriate for fairly absorbing carbonaceous aerosols. Koch et al. (2009) showed that most global BC models have underestimated their BC absorption optical depth;this would cause the models to underestimate BC semi-direct effects. Recently many global models have included aerosol mixing, with enhanced absorption as BC mixes with other chemical species. This will enhance the AA effects on clouds. On the other hand, it should also be noted that BC is co-emitted with other mostly scattering aerosol species such as organic carbon and sulfur dioxide that oxidizes to sulfate, so the single scattering albedo of a given source will be larger than that of $\mathrm{BC}$ alone. From a mitigation perspective, the most relevant issue ultimately is the cloud response to particular sources containing BC.

Although this review has not considered aerosol microphysical, or indirect, effects on clouds, in the real world and in some studies, there are concurrent semi-direct and indirect effects. For liquid clouds, aerosol indirect effects enhance cloud brightness and therefore generally cause a negative cloud radiative effect. Some studies reviewed here showed increased cloud response for increased particle number and/or microphysical impact (e.g. Koren et al., 2008; Hill and Dobbie, 2008). Typically model studies considering indirect effects do not distinguish indirect effect cloud responses from semi-direct effect responses. However this is probably only crucial for very absorbing aerosols because, as discussed above, the semi-direct effect is smaller for large single scattering albedo. One study (Lohmann and Feichter, 2001) showed that for BC and sulfate together, the indirect effect was much larger than the semi-direct effect.

Accurate simulation of absorbing aerosols and simulation of clouds are both challenging for global models. The models have coarse vertical resolution and must accurately capture both the vertical transport and removal of partially hydrophilic particles in convective plumes. Furthermore accurate simulation of biomass burning plumes is generally not parameterized in global models. The vertical distribution of AAs in global models has undergone little constraint due to limited observational information, however this distribution is especially diverse among models (e.g. Textor et al., 2006; Koch et al., 2009). In those regions where models have been tested, the performance is often not very good. Compared with a few aircraft BC profiles in the North American region, most models overestimated BC aloft (Koch et al., 2009). Recently available CALIPSO satellite retrievals are beginning to help models validate their vertical aerosol distributions. However this product must be combined with an indicator of aerosol absorption, such as the OMI aerosol index, to identify the presence of absorbing aerosols. In addition, since the cloud response is clearly sensitive to single scattering albedo, this must also be constrained, e.g. from AERONET and insitu measurements.

We may also question whether global model cloud schemes are able to reproduce the AA-cloud relations captured by cloud-scale models. For example, studies focused on the impacts of AAs on marine stratocumulus (e.g. Johnson et al., 2004; Hill and Dobbie, 2008) have noted that these clouds are not well simulated by global models. Smallscale cloud changes, such as cloud layer thickness, cloud-top entrainment, cloud fraction and the tendency to drizzle are affected by subtle interactions among radiation, turbulence and moist physics on small horizontal and vertical scales. Johnson (2005) compared the marine stratocumulus cloud response from the NCAR single column model with simulations using an LES model and found that the latter had a response larger by a factor of five. On the other hand, cloudscale models are limited in their ability to include climate feedbacks.

Indeed, some of the global model studies emphasized the importance of using a model in which other aspects of the climate can respond to aerosol forcing to accurately include AA effects on clouds. For example, Wang (2004) found much larger cloud changes when using a Qflux model compared to a model with fixed SSTs. Several climate model studies (Wang, 2004; Penner et al., 2003; Roeckner et al., 2006) found that $\mathrm{BC}$ did not warm the climate due to compensatory cloud cooling. It has also been argued that climate models have BC efficacy less than 1 due to cloud changes (e.g. Hansen et al., 2005; Yoshimori and Broccoli, 2008). Model studies that do not include such climate responses would also lack a full cloud response. 
However, global climate models are already known to be diverse in the magnitude of their cloud feedbacks in response to the climate warming from increased $\mathrm{CO}_{2}$ (e.g. Soden and Held, 2006). Therefore we may expect similar diversity in cloud cover response to AAs simply because of basic differences in the model cloud feedback behaviors. It is interesting to note that in the GISS model, low-level low-mid-latitude cloud cover generally decreases in response to increasing $\mathrm{CO}_{2}$ (Del Genio et al., 2005a, b), however low-level cloud cover generally increases in these regions in response to absorbing aerosols (Perwitz and Miller, 2010). Therefore in this case the AAs would have to counter the tendency of the model to decrease low-level clouds under the warmer conditions resulting from aerosol absorption. Modeling AA effects on clouds is more challenging compared to greenhouse gas effects, due to their short lifetime and heterogeneous distribution in the atmosphere.

Due to the tendency for absorbing aerosols to absorb radiation within their relatively thin pollution layer, to stabilize the atmosphere below, to block incoming solar radiation, and to increase low-level cloud cover, they should cause a larger column-to-surface heating ratio than greenhouse gases do. Models in which this is particularly strong may have relatively small surface warming even though the atmospheric column warms more strongly. These effects should be examined in future studies.

Several global models studies (Perlwitz and Miller, 2010; Wang, 2004; Hansen et al., 2005; Penner et al., 2003; Roberts and Jones, 2004; Roeckner et al., 2006) using different global climate models (GISS, CSM-NCAR, Grantour, Hadley Centre, ECHAM5) indicate a net negative semi-direct effect for absorbing aerosols. We should note that although most studies do not report the statistical significance of their results, two studies indicate a very large standard deviation for the semi-direct effect. Penner et al. (2003) estimated a standard deviation about equal to the semi-direct effect, $-0.39 \pm 0.38 \mathrm{Wm}^{-2}$ and Wang (2004) estimated one that was double the effect, $-0.16 \pm 0.31 \mathrm{Wm}^{-2}$. Cloud cover interannual variability in global models is large, and it is not surprising that these aerosol impacts would also be quite variable; this contributes to the uncertainty in the semi-direct estimations.

Because of the potentially cooling semi-direct effects of $\mathrm{BC}$, we need to improve our understanding of AA-cloud interactions as we consider $\mathrm{BC}$ for a global warming mitigation target. Future research should include ongoing comparison of model BC vertical distribution using aircraft data and CALIPSO retrievals. Global model cloud responses to absorbing aerosols could be tested by focusing on particular field studies involving absorbing aerosols and clouds, performing cloud-scale models for that case, and comparing the global model cloud response in a similar environment. Ideally models should be constrained by measurements of aerosol optical properties such as aerosol absorption optical depth, cloud cover and liquid water and indication of atmo- spheric stability, for different pollution amounts. The field study of Brioude et al. (2009) is a good example of combining satellite/model derived information on clouds and meteorology to understand how clouds respond to absorbing aerosols. Similar studies in various environments, would be very useful. Cloud and global models could then attempt to replicate the field studies, with the goal to test and improve the global model cloud response.

Acknowledgements. We thank Olivier Boucher, Ralph Kahn, Tami Bond and an anonymous reviewer for their helpful comments. We also acknowledge helpful discussions with members of the Bounding Black Carbon author group. This study was supported by NASA MAP.

Edited by: J. Quaas

\section{References}

Ackerman, A. S., Toon, O. B., Stevens, D. E., Heymsfield, A. J., Ramanathan, V., and Welton, E. J.: Reduction of tropical cloudiness by soot, Science, 288, 1042-1047, 2000.

Allen, R. J. and Sherwood, S. C.: The aerosol-cloud semi-direct effect and land-sea temperature contrast in a GCM, Geophys. Res. Lett., 37, L07702, doi:10.1029/2010GL042759, 2010.

Andrews, T. and Forster, P. M.: $\mathrm{CO}_{2}$ forcing induces semi-direct effects with consequences for climate feedback interpretations, Geophys. Res. Lett., 35, L04802, doi:10.1029/2007GL032273, 2008.

Brioude, J., Cooper, O. R., Feingold, G., Trainer, M., Freitas, S. R., Kowal, D., Ayers, J.K., Prins, E., Minnis, P., McKeen, S. A., Frost, G. J., and Hsie, E.-Y.: Effect of biomass burning on marine stratocumulus clouds off the California coast, Atmos. Chem. Phys., 9, 8841-8856, doi:10.5194/acp-9-8841-2009, 2009.

Chen, T., Rossow, W. B., and Zhang, Y.-C.: Radiative effects of cloud-type variations, J. Climate, 13, 264-286, doi:10.1175/1520-0442(2000)013<0264:REOCTV > 2.0.CO;2, 2000.

Chung, C. E., Ramanathan, V., and Kiehl, J. T.: Effects of the South Asian absorbing haze on the northeast monsoon and surface-air heat exchange, J. Clim., 15, 2462-2476, 2002.

Chung, C. and Ramanathan, V.: Weakening of the North Indian SST gradients and the monsoon rainfall in India and the Sahel, J. Clim., 19, 2036-2045, 2006.

Chung, C. E., Ramanathan, V., Kim, D., and Podgorny, I. A.: Global anthropogenic aerosol direct forcing derived from satellite and ground-based observations, J. Geophys. Res., 110, D24207, doi:10.1029/2005JD006,356, 2005.

Chung, S. H. and Seinfeld, J. H.: Climate response of direct radiative forcing of anthropogenic black carbon, J. Geophys. Res., 110, D11102, doi:10.1029/2004JD005441, 2005.

Del Genio, A. D., Kovari, W., Yao, M.-S., and Jonas, J.: Cumulus microphysics and climate sensitivity, J. Climate, 18, 2376-2387, 2005a.

Del Genio, A. D., Wolf, A. B., and Yao, M.-S.: Evaluation of regional cloud feedbacks using single-column models. J. Geophys. Res., 110, D15S13, doi:10.1029/2004JD005011, 2005b.

Fan, J., Zhang, R., Tao, W.-K., and Mohr, K. I.: Effects of aerosol optical properties on deep convective clouds 
and radiative forcing, J. Geophys. Res., 113(D8), D08209, doi:10.1029/2007JD009257, 2008.

Feingold, G., Jiang, H., and Harrington, J. Y.: On smoke suppression of clouds in Amazonia, Geophys. Res. Lett., 32, L02804, doi:10.1029/2004GL021369, 2005.

Flanner, M. G., Zender, C. S., Randerson, J. T., and Rasch, P. J.: Present-day climate forcing and response from black carbon in snow, J. Geophys. Res., 112, D11202, doi:10.1029/2006JD008003, 2007.

Hansen, J., Sato, M., and Ruedy, R.: Radiative forcing and climate response, J. Geophys. Res., 102, 6831-6864, 1997.

Hansen, J., Mki. Sato, R. Ruedy, et al.: Efficacy of climate forcings, J. Geophys. Res., 110, D18104, doi:10.1029/2005JD005776, 2005.

Hill, A. A. and Dobbie, S.: The impact of aerosols on nonprecipitating marine stratocumulus. II: The semi-direct effect, Q. J. Roy. Meteor. Soc., 134(634), 1155-1165, doi:10.1002/qj.277, 2008 .

Jacobson, M. Z.: Control of fossil-fuel particulate black carbon and organic matter, possibly the most effective method of slowing global warming, J. Geophys. Res., 107(D19), 4410, doi:10.1029/2001JD001376, 2002.

Johnson, B. T., Shine, K. P., and Forster, P. M.: The semidirect aerosol effect: Impact of absorbing aerosols on marine stratocumulus, Q. J. Roy. Meteor. Soc., 130(599), 1407-1422, doi:10.1256/qj.03.61, 2004.

Johnson, B. T.: The semi-direct aerosol effect: Comparison of a single-column model with large eddy simulation for marine stratocumulus, J. Clim., 18, 119-130, 2005.

Jones, A., Haywood, J. M., and Boucher, O.: Aerosol forcing, climate response and climate sensitivity in the Hadley Centre climate model, J. Geophys. Res., 112, D20211, doi:10.1029/2007JD008688, 2007.

Koch, D., Schulz, M., Kinne, S., McNaughton, C., Spackman, J. R., Balkanski, Y., Bauer, S., Berntsen, T., Bond, T. C., Boucher, O., Chin, M., Clarke, A., De Luca, N., Dentener, F., Diehl, T., Dubovik, O., Easter, R., Fahey, D. W., Feichter, J., Fillmore, D., Freitag, S., Ghan, S., Ginoux, P., Gong, S., Horowitz, L., Iversen, T., Kirkevåg, A., Klimont, Z., Kondo, Y., Krol, M., Liu, X., Miller, R., Montanaro, V., Moteki, N., Myhre, G., Penner, J. E., Perlwitz, J., Pitari, G., Reddy, S., Sahu, L., Sakamoto, H., Schuster, G., Schwarz, J. P., Seland, Ø., Stier, P., Takegawa, N., Takemura, T., Textor, C., van Aardenne, J. A., and Zhao, Y.: Evaluation of black carbon estimations in global aerosol models, Atmos. Chem. Phys., 9, 9001-9026, doi:10.5194/acp-9-9001-2009, 2009.

Koren, I., Kaufman, Y. J., Remer, L. A., and Martins, J. V.: Measurement of the effect of Amazon smoke on inhibition of cloud formation, Science, 303, 1342-1345, 2004.

Koren, I., Martins, J. V., Remer, L. A., and Afargan, H.: Smoke invigoration versus inhibition of clouds over the Amazon, Science, 321, 946, doi:10.1126/science.1159185, 2008.

Lau, K. M., Kim, M. K., and Kim, K. M.: Asian summer monsoon anomalies induced by aerosol direct forcing: The role of the Tibetan Plateau, Clim. Dynam., 26(7-8), 855-864, 2006.

Lohmann, U. and Feichter, J.: Can the direct and semi-direct aerosol effect compete with the indirect effect on a global scale?, Geophys. Res. Lett., 28, 159-161, 2001.

McFarquhar, G. M. and Wang, H.: Effects of Aerosols on Trade
Wind Cumuli over the Indian Ocean: Model Simulations, Q. J. R. Meteorol. Soc., 132, 821-843, 2006.

Menon, S., Hansen, J., Nazarenko, L., and Luo, Y.: Climate effects of black carbon aerosols in China and India, Science, 297, 22502253, 2002.

Menon, S. and Del Genio, A. D.: Evaluating the impacts of carbonaceous aerosols on clouds and climate, in: Human-Induced Climate Change: An Interdisciplinary Assessment, edited by: Schlesinger, M. E., Kheshgi, H., Smith, J. B., de la Chesnaye, F. C., Reilly, J. M., Wilson, T., and Kolstad, C., Cambridge University Press, 34-48, 2007.

Miller, R. L., Tegen, I., and Perlwitz, J.: Surface radiative forcing by soil dust aerosols and the hydrologic cycle, J. Geophys. Res. 109(D4), D04203, doi:10.1029/2003JD004085, 2004.

Norris, J. R.: Has northern Indian Ocean cloud cover changed due to increasing anthropogenic aerosol?, Geophys. Res. Lett., 28, 3271-3274, 2001.

Penner, J. E., Zhang, S. Y., and Chuang, C. C.: Soot and smoke aerosol may not warm climate, J. Geophys. Res., 108(D21), 4657, doi:10.1029/2003JD003409, 2003.

Perlwitz, J., and Miller, R. L.: Cloud cover increase with increasing aerosol absorptivity - A counterexample to the conventional semi-direct aerosol effect, J. Geophys. Res., 115, D08203, doi:10.1029/2009JD012637, 2010.

Ramanathan, V., Chung, C., Kim, D., Bettge, T., Buja, L., Kiehl, J. T., Washington, W. M., Fu, Q., Sikka, D. R., and Wild, M.: Atmospheric brown clouds: Impacts on South Asian climate and hydrological cycle, P. Natl. Acad. Sci. USA, 102(15), 53265333, doi:10.1073/pnas.0500656102, 2005.

Randles, C. A. and Ramaswamy, V.: Absorbing aerosols over Asia: A GFDL general circulation model sensitivity study of model response to aerosol optical depth and aerosol absorption, J. Geophys. Res., 113, D21203, doi:10.1029/2008JD010140, 2008.

Roberts, D. L. and Jones, A.: Climate sensitivity to black carbon aerosol from fossil fuel combustion, J. Geophys. Res., 109, D16202, doi:10.1029/2004JD004676, 2004.

Roeckner, E., Stier, P., Feichter, J., Kloster, S., Esch, M., and Fischer-Bruns, I.: Impact of carbonaceous aerosol emissions on regional climate change, Clim. Dynam., 27, 552-571, 2006.

Rudich, Y., Sagi, A., and Rosenfeld, D.: Influence of the Kuwait oil fire plumes (1991) on the microphysical development of clouds, J. Geophys. Res., 108(D15), 4478, doi:10.1029/2003JD003472, 2003.

Sato, M., Hansen, J., Koch, D., Lacis, A., Ruedy, R., Dubovik, O., Holben, B., Chin, M., and Novakov, T.: Global atmospheric black carbon inferred from AERONET, P. Natl. Acad. Sci., 100, 6319-6324, doi:10.1073/pnas.0731897100, 2003.

Schulz, M., Textor, C., Kinne, S., Balkanski, Y., Bauer, S., Berntsen, T., Berglen, T., Boucher, O., Dentener, F., Guibert, S., Isaksen, I. S. A., Iversen, T., Koch, D., Kirkevåg, A., Liu, X., Montanaro, V., Myhre, G., Penner, J. E., Pitari, G., Reddy, S., Seland, Ø., Stier, P., and Takemura, T.: Radiative forcing by aerosols as derived from the AeroCom present-day and pre-industrial simulations, Atmos. Chem. Phys., 6, 5225-5246, doi:10.5194/acp-6-5225-2006, 2006.

Seinfeld, J. H. and Pandis, S. N.: Atmospheric chemistry and physics: From air pollution to climate change, John Wiley \& Sons, Inc., New York, USA, 1998.

Soden, B. J. and Held, I. M.: An assessment of climate feedbacks 
in coupled ocean-atmosphere models, J. Clim., 19, 3354-3360, 2006.

Stephens, G. L., Wood, N. B., and Pakula, L. A.: On the radiative effects of dust on tropical convection, Geophys. Res. Lett., 31, L23112, doi:10.1029/2004GL021342, 2004.

Stevens, B., Ackerman, A. S., Albrecht, B. A., Brown, A. R., Chlond, A., Cuxart, J., Duynkerke, P. G., Lewellen, D. C., Macvean, M. K., Neggers, R. A. J., Sanchez, E., Siebesma, A. P., and Stevens, D. E.: Simulations of trade wind cumuli under a strong inversion, J. Atmos. Sci., 58, 1870-1891, doi:10.1175/1520-0469(2001)058, 2001.

Textor, C., Schulz, M., Guibert, S., Kinne, S., Balkanski, Y., Bauer, S., Berntsen, T., Berglen, T., Boucher, O., Chin, M., Dentener, F., Diehl, T., Easter, R., Feichter, H., Fillmore, D., Ghan, S., Ginoux, P., Gong, S., Grini, A., Hendricks, J., Horowitz, L., Huang, P., Isaksen, I., Iversen, I., Kloster, S., Koch, D., Kirkevåg, A., Kristjansson, J. E., Krol, M., Lauer, A., Lamarque, J. F., Liu, X., Montanaro, V., Myhre, G., Penner, J., Pitari, G., Reddy, S., Seland, Ø., Stier, P., Takemura, T., and Tie, X.: Analysis and quantification of the diversities of aerosol life cycles within AeroCom, Atmos. Chem. Phys., 6, 1777-1813, doi:10.5194/acp-61777-2006, 2006.
Wang, C.: A modeling study on the climate impacts of black carbon aerosols, J. Geophys. Res., 109, D03106, doi:10.1029/2003JD004084, 2004.

Yoshimori, M. and Broccoli, A. J.: Equilibrium response of an atmosphere-mixed layer ocean model to different radiative forcing agents: Global and zonal mean response, J. Clim., 21, 43994423, 2008.

Zhang, H., Wang, Z. L., Guo, P. W., and Wang, Z. Z.: A modeling study of the effects of direct radiative forcing due to carbonaceous aerosol on the climate in East Asia, Adv. Atmos. Sci., 26(1), 57-66, doi:10.1007/s00376-009-0057-5, 2009. 